\title{
Spectres of Coke: Judicial supervision as a revolutionary inheritance
}

\section{Jacques de Ville}

\begin{abstract}
Sir Edward Coke is known for having played a central role in establishing the power of the common law courts to exercise a supervisory jurisdiction over the executive/administration. Coke is usually praised in the literature for his boldness in doing this, whilst he is at the same time censured for having dared to suggest that this jurisdiction should be a very wide one. This essay questions the inheritance of judicial supervision and enquires whether there may be a secret to uncover in Coke's texts. Referring to Coke's Institutes, it is suggested that the wide jurisdiction of the common law courts that Coke advanced, is linked to and should be understood in light of Coke's pronouncements in the epigrams on law and justice. Judicial supervision, according to this reading of Coke, involves not only a necessarily limited jurisdiction in accordance with law, but also the desire for an unlimited jurisdiction, which corresponds with Derrida's analysis of justice and law. This reading of Coke, it is suggested, calls on us to view judicial supervision as revolutionary in nature which requires of the courts to fundamentally rethink the way in which they exercise their supervisory function.
\end{abstract}

Keywords Coke, Derrida, epigrams, justice, hospitality, Marx, reason, review, sovereignty, spectre

'Let us consider first of all, the radical and necessary heterogeneity of inheritance, the difference without opposition that has to mark it, a "disparate" and a quasi-juxtaposition without dialectic (the very plural of what we will later call Marx's spirits). An inheritance is never gathered together, it is never one with itself. Its presumed unity, if there is one, can consist only in the injunction to reaffirm by choosing. "One must" means one must filter, sift, criticize, one must sort out several different possibles that inhabit the same injunction. And inhabit it in a contradictory fashion around a secret. If the readability of a legacy were given, natural, transparent, univocal, if it did not call for and at the same time defy interpretation, we would never have anything to inherit from it. We would be affected by it as by a cause - natural or genetic.'

Jacques Derrida ${ }^{1}$

\footnotetext{
* An earlier version of this article was presented at a colloquium hosted by the Research Unit for Legal and Constitutional Interpretation, 20-21 October 2005 at the University of Cape Town. I would like to express my thanks to the participants (specifically to André van der Walt) as well as to the referees of this article for their helpful comments. Johan van der Walt must be thanked for reading Derrida's Specters of Marx (infra n. 1) with me (as part of a discussion group) for the first time. Remaining errors are my own.
} 


\section{INTRODUCTION}

Although the state of judicial review today seems healthier than ever, at least in the minds of certain commentators, this article aims at revisiting its origins. Such an enquiry may raise certain questions. It could for example be asked whether the topic has not already been sufficiently exhausted and why the ghosts of the past should be disturbed if they have been put to rest. The ghosts or spectres (yes, plural) that are at issue here are those of Chief Justice, Sir Edward Coke (1552-1634) (hereafter 'Coke'). This article aims at taking seriously what Derrida tells us in the quotation above as well as in some of his other texts ${ }^{2}$ about inheritance. Applied to the origins of judicial review it would imply conjuring Coke's spirits as spectres (a spectre always being animated by a spirit), 3 calling them up, without driving them away. 4 This would entail closely reading the texts of Coke in tracing the origins of judicial review as meticulously as possible.5 The way in which the texts of Coke will be read here would thus not simply be another attempt to repeat or to conserve the heritage that we know so well. ${ }^{6}$ What will be attempted here is to look for the tensions, the contradictions, the heterogeneinity within Coke's texts. 7 As we will see from the analysis that follows, the texts that attest to the origins of judicial review do not speak simply of responsibility based on knowledge as is usually assumed. Instead we find there a certain madness, a certain lack of knowledge, an aporia, undecidability. This is a secret we share with Coke; a secret we mostly prefer to forget or to suppress. It cannot be transmitted from generation to generation; and if it can be transmitted, this will only be as a secret that remains a secret. In a sense, therefore, it has no history, but it nevertheless dictates the following to us, that is, to each new generation: we must always start over. ${ }^{8}$

\section{REVIEW JURISDICTION}

In 1600 or 1601 , we are informed in the Chronology of Events in The Selected Writings and Speeches of Sir Edward Coke, 9 Shakespeare's Hamlet was performed for the first time:

Hamlet:...Sweare.

\footnotetext{
${ }^{1}$ Specters of Marx: The State of the Debt, the Work of Mourning, \& the New International (New York and London: Routledge, 1994), 16.

${ }^{2}$ Ibid., at 21; J. Derrida, Negotiations: Interventions and Interviews, 1971-2001 (Stanford, California: Stanford University Press, 2004), 110-111; J. Derrida, On Cosmopolitanism and Forgiveness (London and New York: Routledge, 2001), 35; 'On Forgiveness: A Roundtable Discussion with Jacques Derrida', in J.D. Caputo et al, eds., Questioning God (Bloomington and Indianapolis: Indiana University Press, 2001), 52-72 at 59.

${ }^{3}$ Derrida, supra n.1, at 3 .

${ }^{4}$ Ibid., at 108 .

${ }^{5}$ Derrida in J.D. Caputo, ed., Deconstruction in a Nutshell: A Conversation with Jacques Derrida (New York: Fordham University Press, 1997), 9.

${ }^{6}$ Ibid.

${ }^{7}$ Ibid.

${ }^{8}$ J. Derrida, The Gift of Death (Chicago: The University of Chicago Press, 1995), 80.

${ }^{9}$ S. Sheppard, ed., The Selected Writings and Speeches of Sir Edward Coke vol 1 (Indianapolis, Indiana: Liberty Fund, 2003), xli.
} 
Ghost [Beneath] Sweare.

[They swear]

Hamlet: Rest, rest, perturbed Spirit! - So, Gentlemen,

With all my loue I doe commend me to you:

And what so poore a man as Hamlet is

Doe t'expresse his loue and friending to you,

God willing, shall not lacke: Let us goe in together,

And still your fingers on your lippes, I pray.

The time is out of ioynt: - Oh cursed spight,

That ever I was borne to set it right.

Nay, come, let's goe together. [Exeunt]

Act I, Scene V10

1600 was also the year in which the first volume of the Reports of Sir Edward Coke was published. Coke lived in a time out of joint, as the history books relating to this period attest to. ${ }^{11}$

The 'origins of judicial review', specifically with reference to the $17^{\text {th }}$ century, is a theme which repeatedly finds its way into academic writing. ${ }^{12}$ These accounts serve inter alia the purpose of confirming what administrative lawyers in common law countries always believed or at least suspected: Judicial supervision has a long and illustrious history with a firm foundation in the $17^{\text {th }}$ century jurisprudence of the common law courts, with Coke having played a significant role in this respect. Furthermore, it is said in these accounts that this supervision is by its nature restricted, in the form of a review rather than an appeal. Most contemporary writers on review tell us that although there have been regressions (especially in the first half of the $2 \mathrm{O}^{\text {th }}$ century) the courts have on the whole (and specifically in the second half of the $2^{\text {th }}$ century) been vigilant in performing their proper functions in relation to executive and administrative authorities. ${ }^{13}$ Moreover, today very little is said to remain of the formalism that beset the jurisprudence on judicial review during the

\footnotetext{
${ }^{10}$ The passage is quoted in Derrida, supra n. 1, at 3.

11 H.J. Berman, Law and Revolution, II: The Impact of the Protestant Reformations on the Western Legal Tradition (Cambridge, Massachusetts: The Belknapp Press of Harvard University Press, 2003), 201-205 refers to the $17^{\text {th }}$ century as the 'European crisis', a crisis which had religious, political and socio-economic dimensions. See also T. Aston, ed., Crisis in Europe 1560-1660: Essays from Past and Present (London: Routledge \& Kegan Paul, 1965); G. Parker and L.M. Smith, eds., The General Crisis of the Seventeenth Century (London: Routledge \& Kegan Paul, 1978).

${ }^{12}$ In the 1950s and 1960s a number of important studies appeared in this respect; see L.L. Jaffe and E.G. Henderson, 'Judicial Review and the Rule of Law: Historical Origins', Law Quarterly Review 72/July (1956), 345-364; L.L. Jaffe, Judicial Control of Administrative Action (Boston and Toronto: Little, Brown and Company, 1965); E.G. Henderson, Foundations of English Administrative Law: Certiorari and Mandamus in the Seventeenth Century (New York: Augustus M. Kelley Publishers, 1963); S.A. de Smith, 'The Prerogative Writs', The Cambridge Law Journal 11/1 (1951), 40-56 (reprinted in J.M. Evans, De Smith's Judicial Review of Administrative Action (London: Stevens \& Sons Ltd, $4^{\text {th }}$ ed, 1980), 584-595); A. Rubinstein, 'On the Origins of Judicial Review', University of British Columbia Law Review 2 (1964-1966), 1-20; and A. Rubinstein, Jurisdiction and Illegality: A Study in Public Law (Oxford: Clarendon Press, 1965), 54-120. Contemporary discussions of the origins of judicial review will be referred to in the footnotes that follow.

${ }^{13}$ See e.g. H.W.R. Wade and C.F. Forsyth, Administrative Law (Oxford: Oxford University Press, $9^{\text {th }}$ ed, 2004), 15-19.
} 
previous three centuries. ${ }^{14}$ Talk of the 'jurisdiction' of administrative authorities has all but disappeared, as has the classification of functions. ${ }^{15}$ It is now regarded as more acceptable, also in the courts, to refer to context and to contextual factors that play a role in determining the appropriate standard of review. ${ }^{16}$ The principle of proportionality is furthermore becoming an acceptable feature of review and fundamental rights play a prominent role. ${ }^{17}$ Administrative law scholars can thus be fairly content these days, it seems. The task facing us, implied by the above account, is a simple one: we should simply continue building on the firm foundation laid for us by Coke in his Reports and Institutes.

Coke's Reports and Institutes are undoubtedly an important part of the tradition of judicial review. The Reports contain some of the first cases, many in which Coke participated as judge, that recognise the supervisory powers of the common law courts. ${ }^{18}$ These include Rooke's Case (1598), ${ }^{19}$ the Case of the Isle of Ely (1609), ${ }^{20}$ the Case of Chester Mill upon the River of Dee (1609), ${ }^{21}$ Dr Bonham's Case (1610),22 and

\footnotetext{
${ }^{14}$ Not everyone will agree with this statement; see e.g. the debate between Allan and Craig on formalism: T.R.S Allan, 'Constitutional Dialogue and the Justification of Judicial Review', Oxford Journal of Legal Studies 23/4 (2003), 563-584; P. Craig, 'The Common Law, Shared Power and Judicial Review', Oxford Journal of Legal Studies 24/2 (2004), 237-257; T.R.S Allan, 'Legislative Supremacy and Legislative Intent: A Reply to Professor Craig', Oxford Journal of Legal Studies 24/4 (2004), 563-583. See also the important contribution of D. Dyzenhaus, 'Formalism's Hollow Victory', New Zealand Law Review (2002), 525-556.

${ }^{15}$ See P. Craig, Administrative Law (London: Thomson/Sweet \& Maxwell, $5^{\text {th }}$ ed, 2003), 407-455, 510-519; C. Hoexter with R. Lyster, The New Constitutional and Administrative Law vol 2 (Cape Town: Juta, 2002), 149$155,189-190$.

${ }^{16}$ See e.g. Bato Star Fishing (Pty) Ltd v Minister of Environmental Affairs and Others 2004 (4) SA 490 (CC) para 45; Baker $v$ Canada (Minister of Citizenship and Immigration) (1999) 174 DLR $\left(4^{\text {th }}\right) 193$ (SCC); $R v$ Secretary of State for the Home Department, ex parte Daly [2001] 3 All ER 433 (HL) paras 27-28.

${ }^{17}$ Craig, Administrative Law, supra n. 15, at 617-632; Wade and Forsyth, supra n. 13, at 366-369; J.R. de Ville, Judicial Review of Administrative Action in South Africa (Durban: LexisNexis Butterworths, 2003), 203-209.

${ }^{18}$ Tracing the origins of judicial review in English law could of course start at a much earlier period, e.g. with the actions and establishment of the powers of Kings; with the establishment of the first administrative officials or bodies (the sheriffs (Anglo-Saxon period), the justices of the peace $\left(12^{\text {th }}\right.$ century) and the sewer commissions $\left(13^{\text {th }}\right.$ century)); with the Curia Regis (established by the Normans after the conquest in 1066) from which developed the common law courts and from where the itinerant justices were sent out to inter alia supervise local government; or with the 'prerogative' writs; see e.g. A. Babington, The Rule of Law in Britain: From the Roman Occupation to the Present Day 3d ed (Chichester: Barry Rose, 1995), 19, 79 (on the sheriffs); 82-84 (on the justices of the peace); 38-39, 70-71 (on the Curia Regis); 77 (on writs); S.B. Chrimes, An Introduction to the Administrative History of Mediaeval England (Oxford: Basil Blackwell, 1952); F.J. Port, Administrative Law (London: Longmans, Green and Co, 1929), 23-54; J.H. Baker, An Introduction to English Legal History $4^{\text {th }}$ ed (London: Butterworths LexisNexis, 2002), 12-26, 143-151.

${ }^{19} 5$ Co. Rep. 99b; see Sheppard, supra n. 9, at 141-144. It was held in this case that the commissioners of sewers may not tax only one landowner for the maintenance of a river bank when other landowners also benefit from such public works. This case was decided by Judge Walmsley, but Jaffe, supra n. 12, at 625 contends that Coke was probably the author of the part of the report on the issue of the scope of the court's supervisory jurisdiction. See also P. Raffield, 'Contract, Classicism, and the Common-Weal: Coke's Reports and the Foundations of the Modern English Constitution', Cardozo Studies in Law and Literature 17 (2005) 69-91 at 72-73 and D. Powell, 'Coke in Context: Early Modern Legal Observation and Sir Edward Coke's Reports', The Journal of Legal History 21/3 (2000) 33-53 at 40-48 on Coke's 'authoring' of the Reports.

${ }^{20} 10$ Co. Rep. 141a; see Sheppard, supra n. 9, at 378-383. The court in this case held that the commissioners of sewers did not have the power to make new rivers and that only those who benefit from public works should be taxed to pay for them.

${ }^{21} 10$ Co. Rep. 137a. The court in this case held that the commissioners of sewers did not have the power to make a breach in a causey which was previously constructed for the upkeep of certain mills.

${ }_{22} 8$ Co. Rep. 113b; see Sheppard, supra n. 9, at 264-283. The court in this case held that the College of Physicians did not have the power to fine or imprison a medical doctor educated at Cambridge.
} 
James Bagg's Case (1615).23 The jurisdiction of the King's Bench as set out in the Institutes is of specific importance for scholars of administrative law. ${ }^{24}$ In the Fourth Part of the Institutes 71, Coke sets out the review jurisdiction of the King's Bench as follows:

[T]his Court hath not only jurisdiction to correct errors in judiciall proceeding, but other errors and misdemeanours extrajudiciall tending to the breach of the peace, or oppression of the subjects, or raising of faction, controversy, debate, or any other manner of misgovernment; so that no wrong or injury, either publick or private, can be done but that this shall be reformed or punished in one Court or other by due course of Law. As if any person be committed to prison, this Court upon motion ought to grant an Habeas corpus, and upon returne of the cause do justice and relieve the party wronged. And this may be done though the party grieved hath no priviledge in this Court. It granteth prohibitions to Courts Temporall and Ecclesiastical to keep them within their proper jurisdiction. Also this Court may baile any person for any offence whatsoever. And if a Freeman in City, Burgh, or Town corporate be disfranchised unjustly, albeit he hath no priviledge in this Court, yet this Court may relieve the party, as it appeareth in James Bagges case, ubi supra \& sic in similibus.

For purposes which should be become clear in the analysis that follows, it should be pointed out at this juncture that Coke also notes in the Fourth Part of the Institutes that the first Chief Justice of the King's Bench, before the reign of Edward I, was created by Letters Patent and that it is to be noted that the Chief Justice was originally instituted for three things:

1. For our preservation. 2. For the tranquillity of our realm. 3. To provide justice to all and singular of our realm. ${ }^{25}$

The above paragraph on jurisdiction contains a summary of the findings of the earliest cases on review, cases which laid the foundation for the further development of the courts' supervisory jurisdiction. ${ }^{26}$ The first sentence comes almost verbatim

\footnotetext{
${ }^{23} 11$ Co. Rep. 93b; see Sheppard, supra n. 9, at 404-417. In this case a writ of restitution was issued to reinstate a burgess to office. A number of other cases can of course also be said to be important in the present context, especially those dealing with the prerogative powers of the King, e.g. Prohibitions del Roy (1607) 12 Co. Rep. 63 and the Case of Proclamations (1611) 12 Co. Rep. 74; for discussion see P. Craig, 'Prerogative, Precedent and Power', in C. Forsyth and I. Hare, eds., The Golden Metwand and the Crooked Cord (Oxford: Clarendon Press, 1998), 65-89 at 67-68; A. Tomkins, Our Republican Constitution (Oxford and Portland, Oregon: Hart Publishing, 2005), 69-74.

${ }^{24}$ As De Smith, Woolf and Jowell Judicial Review of Administrative Action (London: Sweet \& Maxwell, $5^{\text {th }}$ ed, 1995), 616 (para 14-001) point out, the jurisdiction of the Queen's Bench Division (as well as that exercised by the superior courts in common-law countries) is 'directly linked to that of the Court of King's Bench in the seventeenth century and earlier'.

${ }^{25}$ Sheppard, supra n. 9, at 1178 (vol II). Coke notes that the third 'thing' mentioned here, 'was the original jurisdiction of this Court'.

${ }^{26}$ E. Jenks, 'The Prerogative Writs in English Law', Yale Law Journal 32/6 (1923), 523-534 at 530-531; Jaffe, supra n. 12, at 329-334; Henderson, supra n. 12, at 72; J. Laws, 'Wednesbury', in C. Forsyth and I. Hare, eds.,
} 
from James Bagg's Case. ${ }^{27}$ Coke's decisions on review were, to put it mildly, not well received by his peers. ${ }^{28}$ Administrative lawyers of the present and previous century, despite their praise for the role Coke played in establishing the institution of judicial review, similarly criticise him, sometimes vehemently, for his decisions on review, and for his views on the scope of the court's supervisory powers. ${ }^{29}$ In the latter respect he has been charged with having set up the judicial power as a 'third force', 'in the day-to-day operation of government' ${ }^{30}$ Regarding his decisions on review, it has inter alia been argued that there was no previous authority for the remedy granted in James Baggs' Case and which later developed into the writ of mandamus. ${ }^{31}$

It seems logical to contend that the jurisdiction of the Court that is laid down in Coke's Institutes should be viewed in the context of the battle over jurisdiction with the other courts ${ }^{32}$ and the question of the prerogative of the King. 33 This history is well-documented and will not be recounted here. We can nonetheless remind ourselves that Coke's views presented a severe threat to James I34 and that his disagreement with the latter regarding these matters would eventually contribute to his dismissal as Chief Justice (in 1616, the year in which Shakespeare died). 35 Because of Coke's central role in these disputes, it can furthermore be fairly safely assumed that his decisions on administrative law matters as well as the matters addressed in the Institutes can be read as not only concerned with correcting the wrongs perpetrated in the specific matters, but with the wrongs of the times; 36 'setting right' the relationship between the King and the courts. 37 The jurisdiction of the court as set

The Golden Metwand and the Crooked Cord (Oxford: Clarendon Press, 1998), 185-201 at 190-191; P. Craig 'Ultra Vires and the Foundations of Judicial Review' in Forsyth, ed., Judicial Review and the Constitution (Oxford: Hart Publishing, 2000), 47-71 at 63; P. Craig, 'Public Law, Political Theory and Legal Theory' Public Law Summer (2000) 211-239 at 231-233; D. Oliver, 'Public Law Procedures and Remedies - Do we need Them' Public Law Spring (2002), 91-110; C. Russell, 'Topsy and the King: The English Common Law, King James VI and I and the Union of the Crowns' Public Law Summer (2005), 336-345 at 337-338.

27 Supra n. 23.

${ }^{28}$ Jaffe and Henderson, supra n. 12 at 353-4 quoting from the Acts of the Privy Council, 1616-1617 at 57. See also Jaffe, supra n. 12, at 207.

${ }^{29}$ Ibid., at 348. See also A.C. Aman and W.T. Mayton, Administrative Law (St Paul, Minn: West Group, 2d ed, 2001), 347 who refer to 'Lord Coke's sweeping assertion of judicial authority'; and Evans, supra n. 12, at 592 where De Smith refers to Coke's 'sweeping proposition'.

${ }^{30}$ Jaffe and Henderson, supra n. 12 at 355.

${ }^{31}$ Jaffe, supra n. 12, at 210, 331; Henderson, supra n. 12, at 72; Jaffe and Henderson, supra n. 12 at 359.

${ }^{32}$ See also Craig, Administrative Law supra n. 15, at 6.

${ }^{33}$ See Berman, supra, n 11, at 201-230, J.G.A. Pocock, The Ancient Constitution and the Feudal Law: A Study of English Historical Thought in the Seventeenth Century (Cambridge: Cambridge University Press, Reissue 1987) 30-55.

${ }^{34}$ As A. Cromartie, 'The Constitutionalist Revolution: The Transformation of Political Culture in Early Stuart England' Past and Present 163 (1999), 76-120 at 100 points out, 'Coke's ideas were dangerous to kings, because the omnicompetence of law supplied him with a never-failing standard by which to judge monarchical behaviour'.

${ }^{35}$ See Lord Campbell, The Lives of the Chief Justices of England vol I (New York: George W. Smith \& Company, 1874), 290-296.

${ }^{36}$ The Second, Third and Fourth Parts of the Institutes were of course published only posthumously, but they were likely prepared between 1629 and 1634. The Twelfth Part of the Reports was published for the first time in 1656 and the Thirteenth Part in 1659; Sheppard, supra n. 9, at lxv and lxvii.

${ }^{37}$ See also Pocock, supra n. 33, at 46 and Raffield, supra, n. 19, at 72, 81-82 and 91 on Coke's use of case law and the Institutes for this purpose. 
out above can, based on this reading, be attributed inter alia to Coke's opposition to absolute monarchy.

The criticism of Coke by administrative lawyers is closely related to the above events. At more or less the same time that Coke was dismissed as Chief Justice, the courts effectively lost their powers of supervision, at least over the sewer commissions, such supervision thereafter taking place through the King's Council and the prerogative courts. 38 With the re-assumption of the power of supervision by the common law courts after the demise of the powers of the Council, the judiciary was seemingly more compliant and interfered only where the issue was jurisdictional in nature. 39 One of the implicit 'messages' relayed by administrative law scholars supportive of the institution of judicial review in recounting its origins seems to be that judges should realise that if they overstep the proper limits of their review powers, they can expect to lose all their powers of supervision. 40

Based on the above and in analysing Coke's dicta on jurisdiction, the reference to justice in the above quotations must presumably be understood with reference to Coke's belief that natural law was incorporated into English common law. ${ }^{41}$ Lewis, ${ }^{42}$ for example, understands Coke as saying that the common law can be equated with the law of nature. He points out that fundamental law, reasonableness and common law are unified as well as identified in Coke's thinking.43 Coke's thinking in this respect furthermore seems to be closely related to the doctrine or cult of the ancient constitution which seventeenth century common lawyers, specifically Coke, believed

\footnotetext{
38 Jaffe and Henderson, supra, n. 12 at 353-355; Jaffe, supra n. 12, at 208; Henderson, supra n. 12, at 34 According to Evans, supra n. 12, at 93-94, although there was a rise in conciliar jurisdiction during this period, this jurisdiction did not purport to be all-embracing. It appears that the Council and the Court of Star Chamber (from the $16^{\text {th }}$ century until the abolishment of the Star Chamber in 1641) were much less concerned than the common law courts with protecting property rights and the liberty of the subject; see G. Radcliffe and G. Cross, The English Legal System (London: Butterworths, $6^{\text {th }}$ ed, 1977), 110-112; W. Holdsworth, A History of English Law vol IV (London: Methuen \& Co Ltd, Reprinted 1966), 70-88.

${ }^{39}$ Jaffe and Henderson, supra n. 12, at 348.

${ }^{40}$ See also the warning of the Lord Chancellor, Ellesmere on the occasion of the swearing in of Sir Henry Montague who replaced Coke as Chief Justice of the King's Bench reported by Rubinstein 'On the Origins of Judicial Review', supra n. 12, at 13; Rubinstein, Jurisdiction and Illegality, supra n. 12, at 71; and see Lord Parker Recent Developments in the Supervisory Powers of the Courts over Inferior Tribunals: Lectures by Lord Parker of Waddington, Lord Chief Justice of England (Jerusalem: Magnes Press 1959) 27-28.

${ }^{41}$ Berman, supra, n 11, at 243-244; Calvin's Case, or the Case of the Postnati (1608) (in Sheppard, supra n. 9, at 166 at 174); M. Loughlin, The Idea of Public Law (Oxford and New York: Oxford University Press, 2003 ), 119. See also P. Raffield, Images and Cultures of Law in Early Modern England: Justice and Political Power (Cambridge: Cambridge University Press, 2004), 1-3, 261-2, 264-267 who reads Coke's views on the common law as aspiring towards a utopian ideal.

42 J.U. Lewis, 'Sir Edward Coke (1552-1634): His Theory of "Artificial Reason" as a Context for Modern Basic Legal Theory', in A.D. Boyer, ed., Law, Liberty and Parliament: Selected Essays on the Writings of Sir Edward Coke (Indianapolis: Liberty Fund, 2004), 107-120 at 115-116

${ }^{43}$ Ibid. See also E. Sandoz, 'Fortescue, Coke, and Anglo-American Constitutionalism' in E. Sandoz, ed., The Roots of Liberty: Magna Carta, Ancient Constitution, and the Anglo-American Tradition of Rule of Law (University of Missouri Press, Columbia 1993), 1-21 at 7 who finds in Sir John Fortescue (ca 1385 - ca 1479), 'Coke's master in the law of the constitution' (at 5), the same idea namely that 'the historically ancient and the ontologically higher law - eternal, divine, natural - are woven together to compose a single harmonious texture'. See also Raffield, supra, n. 19, at 71; and Cromartie, supra n. 34, at 87-88.
} 
in.44 On this reading, when Coke therefore says that a court, in exercising its supervisory jurisdiction, must remedy injustices, he was saying no more, in today's terms, than that an appropriate judicial remedy needs to be granted where a review ground is present (although this was stated in broader terms than is today regarded as 'appropriate'). 'Appropriateness' is furthermore to be determined in accordance with reason; the reason of 'an infinite number of grave and learned men' 45 who know what is needed for our preservation, for the tranquillity of our realm, for providing justice to all and singular of our realm. ${ }^{6}$ The paragraph on jurisdiction thus speaks of the sovereign reasoning of the respectable, right-thinking bourgeois 47 as well as of the friend as the brother. 48 The protection of the right to property, of the inherited liberty of free men 49 and of existing rights was and is of course central to this mode of reasoning. 50

On this reading we can conclude that Coke was similar to Hegel's Hamlet: a Hamlet who (in Hegel's view) has wrongly been depicted as being indecisive in what he should do. In Hegel's view Hamlet is in actual fact resolute in what he has set out to do, merely being indecisive in how he should do it. ${ }^{51}$ Into the turbulent times of the seventeenth century thus stepped not a Hamlet of uncertainty, but someone even more sure of himself than Hegel's Hamlet - a Hamlet who knew exactly how to put things right..$^{2}$ Coke, on this reading, is not Derrida's Hamlet: a Hamlet who is called on by his father's ghost to do justice, but in whom we can see 'the hesitation to take revenge, the deliberation, the non-naturality or the non-automaticity of the calculation: neurosis, if you like'.53 Derrida's Hamlet faces the abyss that is opened up

\footnotetext{
${ }^{44}$ See Pocock, supra n. 33; J.G.A. Pocock, Politics, Language and Time: Essays on Political Thought and History (London: Methuen \& Co Ltd, 1960), 202-232; M. Loughlin, Public Law and Political Theory (Oxford: Clarendon Press, 1992), 42-46, 151.

${ }^{45}$ See the First Part of the Institutes 97b (Sheppard, supra n. 9, at 701 (vol II)).

${ }^{46}$ See supra.

${ }^{47}$ J. Derrida Rogues: Two Essays on Reason (Stanford, California: Stanford University Press, 2005) 64, 69, 101.

${ }^{48}$ See J. Derrida, Politics of Friendship (London and New York: Verso, 1997).

${ }^{49}$ See e.g. Ch 9 of the Magna Carta as discussed by Coke in the Second Part of the Institutes. See, however, also Ch 29 which does protect certain freedoms of certain women.

${ }^{50}$ J.W. Gough, Fundamental Law in English Constitutional History (Oxford: Clarendon Press, 1955), 54; Craig, Administrative Law supra n. 15, at 9, 416. See also Raffield, supra, n. 19, at 79 and 89 where the author identifies landowners and entrepreneurs as the principal beneficiaries of Coke's interpretation of the law. Tomkins, supra n. 23, at 73-74 is to the same effect. P. Raffield, 'Bodies of Law: The Divine Architect, Common Law and the Constitution', International Journal for the Semiotics of Law 13 (2000) 333-356 at 348352, 355 and Pocock, supra n. 44, at 211-212 similarly stress the importance of the protection of property which underlies the English common law. See further The First Part of the Institutes section 279b: "“A right cannot die." Dormit aliquando jus, moritur nunquam. For of such an high estimation is right in the eye of the law, as the law preserveth it from death and destruction: trodden downe it may bee, but never trodden out.'

${ }^{51}$ G.W.F. Hegel, Aesthetics: Lectures on Fine Art vol I (Oxford: Clarendon Press, 1975), 244.

${ }^{52}$ Coke is said to not have had a high regard for actors - he regarded them as vagrants, which may account for the fact that Shakespeare satirised him in Twelfth Night; or What you Will; see Act III Scene 2 (Toby to Aguecheek). Coke's speech at the treason trial of Sir Walter Raleigh (1603 - where Coke, as Attorney-General, was the prosecutor, 'employing disgraceful invective and unfair tactics') is said to have been used by Shakespeare; see C.D. Bowen, The Lion and the Throne: The Life and Times of Sir Edward Coke (1552-1634) (Boston: Little, Brown \& Co, 1956), 196fn; H.W. Woolrych, The Life of The Right Honourable Sir Edward Coke, Knt, Lord Chief Justice of the King's Bench (Rothman Reprints, South Hackensack New Jersey, 1826; Reprint 1972), 66-68; Sheppard, supra n. 9, at xliii.

${ }^{53}$ Derrida, supra n. 1, at 26.
} 
through the differential and deferential relationship between law and justice, a justice which remains forever out of joint.54

\section{REVIEW JURISDICTION RE-VIEWED}

The above account as well as that of authors who have written on Coke is based on a reading of Coke's texts as a unity, as conveying a central message, even though different interpretations are adopted. What would be the consequence if we instead view Coke's texts as being heterogeneous in nature? May there then perhaps be a secret to uncover in Coke's texts? Coke may be said to have already anticipated such a reading of his texts. In the Preface to Part Three of the Reports55 he says that judges should not have to give reasons for every case that they decide. If they were to do so, judges would not have time to render other services to the Commonwealth, case records would become too voluminous, and judgments would lose some of their authority and reverence. He continues:

But mine advice is, that whensoever a man is enforced to yeeld a reason of his opinion or judgement, that then hee set down all authorities, presidents, reasons, arguments, and inferences whatsoever that may bee probably applied to the case in question; For some will be perswaded, or drawne by one, and some by another, according as the capacitie or understanding of the hearer or reader is. These Records for that they contain great and hidden treasure, are faithfully and safely kept (as they well deserve) in the Kings treasurie. 56

In reading Coke, a distinction has to be drawn between his philosophy or theoretical approach and his texts. The 'theoretical approach' of Coke, as set out above also in relation to judicial supervision, is necessarily an abstraction and a simplification. Conjuring the spirit of Coke usually results in immediately reducing his texts, through a wilful imposition, to a singular, domesticated meaning 57 where instead there is heterogeneity. The Cokean inheritance as we find it in academic books and journals is absolutely and thoroughly determinate, and it is likely to remain that way. $5^{8}$ The text from which Coke's theoretical approach has been excised is however 'complex and heterogeneous, a multiplex of innumerable threads and layers'.59 There is in other words more than one spirit/spectre of Coke, there must be more than one of them, Derrida would say. ${ }^{60}$ Coke, in spite of himself, quotes with seeming approval,

\footnotetext{
${ }^{54}$ J. Derrida and E. Roudinesco, For What Tomorrow...A Dialogue (Stanford, California: Stanford University Press, 2004), 81.

${ }_{55}^{5}$ Sheppard, supra n. 9, at 60.

${ }^{56}$ Ibid (emphasis added).

57 See also J.R. Stoner, Common Law and Liberal Theory: Coke, Hobbes, and the Origins of American Constitutionalism (Kansas: University Press of Kansas, 1992), 16 on the supposed integrity and simple unity of Coke's work, also in his own view.

${ }^{58}$ See J. Derrida, 'Spectres of Marx', New Left Review 205 (1994) 31-58 at 33 on the Marxist inheritance.

${ }^{59}$ See Caputo, supra n. 5, at 82; B. Johnson 'Translator's Introduction', in J. Derrida Dissemination (London and New York: Continuum, 2004 ed) xv.

${ }^{60}$ Derrida, n. 56, at 33.
} 
statements (which, based on a traditional reading would be regarded as merely for ornamentation) on the relationship between law and justice which do not fit into the above theoretical account of his thinking as a whole. Let us note a few of Coke's dicta on law and justice. In the epigrams from the title page of Part Two of the Reports the following dicta appear in relation to law:

PAPIAN. Lib. I. Definit.

Law is a universal command, the resolution of prudent men, restraining offences (whether knowingly or unwittingly committed), a general consensus of the common weal.

ISODORUS

Lex (law) is so called from ligando (binding), because it binds, or it is so called from legendo (reading), because it is read out in public.

CIC. Lib. I. de Legibus

When I say the law, I wish nothing else to be understood to be said by me but imperium (authority), without which no house, no city, no people, nor any kind of man, nor the nature of things, nor even the world itself, can stand. 61

In the epigrams from the title page of part 10 of the Reports (in which the Case of the Isle of Ely and the Case of Chester Mill are reported), ${ }^{62}$ the following statement on justice appears:

St Jerome: Justice did not know a father, mother, or brother, and did not take on a personality; but it imitates God. 63

Thus far, these epigrams have generally 64 been treated in the literature as something which can be ignored: mere supplements of or ornamentations to the text. ${ }^{65}$ Coke nevertheless uses epigrams to frame the Reports as well as the Institutes. They are neither the work (ergon) nor outside the work. ${ }^{66}$ Why does Coke do so if they are not needed? Does it perhaps show some lack in the Reports and the Institutes 'themselves'? Do the epigrams perhaps express something which could not be stated 'in' the Reports and the Institutes, 'things' so disruptive that they could not be said

\footnotetext{
${ }^{61}$ Sheppard, supra n. 9, at 37-38.

${ }^{62}$ See n. 20 and 21 supra.

${ }^{63}$ Ibid., at 327.

${ }^{64}$ N. Mathews, Francis Bacon: The History of a Character Assassination (Yale University Press, 1996) starts his book with an epigram from Coke: 'The slander of a dead man is a living fault'. The literature on Coke is vast (see Sheppard, supra n. 9, at 1341-1377 (vol III) for a representative list). It is likely that there have been other references in the literature to Coke's epigrams, although these are unlikely to have emphasized the paradoxes that may result from such references.

${ }^{65}$ Raffield, supra n. 41, at 13-14, 18, 31, 41, 49, 63, 128-129, 206; Raffield, supra n. 50, at 335, 345 and 347; Raffield, supra, n. 19, at 71, 73, 76, 81, 82; and P. Raffield, 'The Failings of Common Lawyers and their Representation in Seventeenth Century Satirical Drama', Cardozo Studies in Law and Literature 17 (2005), 365389 at 383 and 385 refers to some of the Prefaces of Coke's Reports and Institutes in his reading of the common law as both insular and protectionist on the one hand and as aspiring towards utopia or as expressing the principles of civic republicanism on the other. Raffield does not refer to the epigrams. Pocock, supra n. 33 also refers frequently to the Prefaces of Coke's Reports.

${ }^{66}$ J. Derrida, The Truth in Painting (Chicago and London: The University of Chicago Press, 1987), 9 on the parergon.
} 
there, but which nevertheless required saying? Do they perhaps express Coke's desires? Epigrams, we know, were first used as inscriptions, and later developed into a form of poetry. ${ }^{67}$ It is defined as 'a witty, often paradoxical remark, concisely expressed'68 or as a 'pointed or antithetical saying'. ${ }^{69}$ Coke's epigrams are not generally marked by paradox or antithesis 'within'. The paradox or antithesis appears rather to be found in relation to the text (understood here in the classical sense as the 'main body' of the written work), but without simply opposing the 'text'. As we can see from the above epigrams, some of them repeat the 'wisdom' that is expressed in the 'text', for example in relation to the question of what law is: a good parergon thus. But there also appear to be perverted parerga, like the epigram above which talks about justice and which appears to say something different from what is stated in the Reports and Institutes; which draws attention to itself and not to the text; a seductive adornment thus like a golden frame. ${ }^{70} \mathrm{~A}$ perverted epigram remains a parergon nonetheless. ${ }^{71}$ The ergon is in need of the parergon, and vice versa:

[T]he ergon is never fully complete, never fully finished, never fully independent, but rather entails an inner lack which calls forth (in an atemporal sense) the parergon to complete it. The painting is never without a frame, whether it is explicitly framed or not. ${ }^{72}$

In spite of the text (in the classical sense) of the Reports and Institutes presenting themselves as complete, as not lacking, the epigrams (presented by Coke and read throughout history as mere ornaments) are thus central and essential to the Reports and the Institutes, providing their orientation; an internal opening in the same.73 Like the frame of a painting, the clothing on statutes, the columns around extravagant buildings, 74 these (perverted) epigrams, in spite of their 'paradoxical' or 'antithetical' nature, are furthermore not subject to the Hegelian Aufhebung 75 as they are neither wholly inside nor wholly outside the Reports and Institutes. ${ }^{6}$ They do not signify or represent anything; they are 'deprived of theme and text (in the classical sense)';77 they are 'vague beauties' without concept and without aim, 78 'the trace of a ghost

\footnotetext{
${ }^{67}$ Marcus Varelius Martialis (ca. 40 - 104 AD) is credited with the development of the modern epigram. He used epigrams to criticise the vices of society; see www.ancientworlds.net/aw/Personas/LoginForm (access confirmed: 22 May 2006).

${ }^{68}$ Collins English Dictionary.

${ }^{69}$ Oxford English Dictionary Online.

${ }^{70}$ Derrida, supra n. 66, at 64.

${ }^{71}$ Ibid.

${ }^{72}$ See I.E. Harvey 'Kant' in H.J. Silverman, ed., Continental Philosophy II: Derrida and Deconstruction (New York and London: Routledge, 1989), 59-76 at 73; see also Derrida, supra n. 66, at 59-60.

${ }^{73}$ See Harvey, supra, n. 72 at $71,74$.

${ }^{74}$ Derrida, supra n. 66, at 57-61.

${ }^{75}$ I.E. Harvey, Derrida and the Economy of Différance (Bloomington: Indiana University Press, 1986) 170, 207208; D. Rathbone, 'Encounters with other Philosophers: Hegel' in J. Reynolds and J. Rolfe, eds., Understanding Derrida (New York and London: Continuum, 2004), 134-142.

76 J. Culler, On Deconstruction: Theory and Criticism after Structuralism (London: Routledge, 1982), 194; Derrida, supra n. 66, at 61.

${ }^{77}$ Derrida, supra n. 66, at 97.

${ }^{78}$ Derrida, supra n. 66, at 92-93 and 96-97.
} 
disorganizing all ontologies, exceeding in its hauntological energy, as the other's signature'.79

Coke's Reports and Institutes can thus be said to have a paradoxical structure. This paradoxical structure is also to be found in relation to more specific issues like that of jurisdiction. In the Preface to the Fourth Part of the Institutes Coke explains the notion of jurisdiction with reference to this paradoxical structure as follows:

We in this Fourth and last part of the Institutes are to speak of the Jurisdiction of the Courts of Justice within this Realm.

Jurisdiction is the authority of adjudicating or stating the law between parties concerning actions of persons and matters, according as they are brought to judgment, by ordinary or delegated authority: And again, Jurisdiction is a power introduced for the public good, on account of the necessity of doing justice. [Jurisdiction is derived from] jus (law) and dicio (authority), that is, authority of law. 80

The clear distinction that Coke draws in the above passage and in the epigrams between law and justice is striking. This justice that must be done (the necessity of justice, Coke says) is not to be understood as justice in accordance with law. Justice, understood as having been incorporated into the common law, Coke seems to be saying here, is no longer justice; justice is thereby neutralised, it loses its disruptive force. 'Justice did not know a father, mother, or brother, and did not take on a personality; but it imitates God', says St Jerome, repeats Coke. Law, which is nothing but authority, protects the oikos, the home, the family, the nation; it is there for our preservation. Justice, on the other hand, does not have a father or mother or brother, and therefore has no concern with the oikos, the home, the family, the nation. By analogy we can say that whereas law according to Coke concerns itself with existing rights, inherited freedoms and property, justice speaks of 'the incalculable equality in a freedom that is alike for all'. ${ }^{81}$ Justice furthermore 'did not take on a personality' Coke says: justice does not exclude the other in order to take on an identity, to become a subject. ${ }^{82}$ Justice, if it exists, is not identical to itself. Justice does not retain mastery/sovereignty of the house. ${ }^{83}$ Justice, if it exists, is absolute hospitality. ${ }^{84}$ Justice concerns a pure gift with no return to the self. 85 Justice cannot be represented in or through law. ${ }^{86}$ Justice remains to come. ${ }^{87}$ Justice 'imitates God' Coke says: The

\footnotetext{
79 J. Wolfreys 'Art' in J. Reynolds and J. Rolfe, eds., Understanding Derrida (New York and London: Continuum, 2004), 84-92 at 90.

${ }^{80}$ Sheppard, supra n. 9 , at 1058 (vol II).

${ }^{81}$ Derrida, supra n. 47 at 49.

${ }^{82}$ Derrida, supra n. 48 , at 68.

${ }^{83}$ J. Derrida, Acts of Religion (New York and London: Routledge, 2002), 363-364.

${ }^{84}$ Derrida supra n. 1 , at 65.

${ }^{85}$ J. Derrida "Force of Law: The "Mystical Foundation of Authority", in D. Cornell et al, eds., Deconstruction and the Possibility of Justice (New York: Routledge, 1992), 3-67 at 25.

${ }^{86}$ Ibid., at 27.

${ }^{87}$ Ibid.
} 
God of St Jerome (and the God of Coke), if s/he exists, is love; 88 and love, if it exists, is 'a gift of infinite love, a goodness that is forgetful of itself. ${ }^{89}$ The love of God is therefore not a love for the self; God, if s/he exists, is the one who loves the stranger, excessively so. ${ }^{\circ 0}$ Justice, if it exists, is an experience of the impossible. Justice has no concern for the self, the home, the family, the nation. Justice, if it exists, is absolute hospitality, ${ }^{91}$ the pure gift, 92 unconditional forgiveness. 93

This raises a number of questions. Why would Coke choose this quotation from St Jerome which can, almost four centuries after he cited it, lead to all kinds of (mis)interpretations, rather than relying on a 'safer' passage which shows the transcendent, 94 yet conditional nature of forgiveness and of justice? In Letter 21(34) St Jerome, in commenting on the parable of the prodigal son, for example says the following:

AND HE [the older brother] ANSWERING SAID TO HIS FATHER: BEHOLD, FOR SO MANY YEARS DO I SERVE THEE. The father as suppliant begs him to make peace. But he, following the justice that is in the law, is not obedient to the justice of God.95 And besides, what is greater than the justice of God, greater than forgiving the penitent and saving a son who returns?96

We can only, no, we must conclude that Coke, despite himself, also spoke of an impossible justice, of absolute hospitality, the pure gift and of unconditional forgiveness.

\section{JURISDICTION AND REVOLUTION}

In the discussion above we saw Coke being acknowledged and praised for bringing about the institution of judicial supervision in the form that we know it today. At the same time, what Coke said in relation to judicial supervision is a cause for great discomfort. This discomfort is perhaps understandable in light of the turmoil (inter alia a bloody civil war and a revolution) ${ }^{97}$ which followed upon (although not necessarily from) Coke's pronouncements. Coke, we can say, is praised (though with some discomfort) as a (bourgeois) revolutionary - a revolutionary who, similar to the great revolutionaries, dared to act 'outside of the law' in founding a new law. .8 The

\footnotetext{
${ }^{88} 1$ John 4:16.

${ }^{89}$ Derrida, supra n. 8, at 51.

90 J. Derrida, Adieu: To Emmanuel Levinas (Stanford, California: Stanford University Press, 1999) 104.

${ }^{91}$ See J. Derrida and A. Dufourmantelle, Of Hospitality (Stanford, California: Stanford University Press, 2000); Derrida, supra n. 83, at 356.

${ }^{92}$ See J. Derrida, Given Time: I. Counterfeit Money (Chicago: The University of Chicago Press, 1992).

${ }^{93}$ Derrida, On Cosmopolitanism and Forgiveness supra n. 2.

${ }^{94}$ A transcendental account of justice would of course also conflict with Coke's legal theory as set out above.

${ }^{95}$ Footnote in text refers to Romans $10.3 \mathrm{ff}$.

${ }^{96}$ J. Quasten and W.J. Burghardt, eds., Ancient Christian Writers: The Works of the Fathers in Translation: The Letters of St. Jerome vol I (Westminster, Maryland: The Newman Press, 1963), 125.

${ }^{97}$ See Henderson, supra n. 12 at 2.

${ }^{98}$ See Derrida and Roudinesco, supra n. 54, at 83 on revolution, understood as seeking to do the impossible.
} 
new law refers here specifically to the law 99 which authorises judicial supervision, determines its scope and the remedies that may be granted. This 'law', although it was founded before the English revolution, was confirmed and re-established through the revolution. Coke wanted to retain (or to bring about) a constitutional monarchy, something which would not happen without a revolution. ${ }^{100}$ Coke's words however testify to the fact that he can be read as not only a bourgeois revolutionary, but a revolutionary inspired (even before Marx) by a certain spirit of Marx; by 'an idea of justice irreducible to [law or to] all the failures of communism'. ${ }^{101}$ As Defoort ${ }^{102}$ points out, nothing is praised as much as that which was done by those who founded a (new) state. However, those same things which are praised are as strictly prohibited from being repeated. Coke's spirit is conjured up as spectre by Jaffe and Henderson, and by De Smith and by Craig and by Aman and Mayton and by others, we can say, simply for the spectre to be silenced, to be driven away. ${ }^{103}$ What we are left with after the conjuration and exorcism is thus no longer a spirit/spectre. 104 Insofar as it can still be identified as a spirit/spectre, it has been thoroughly domesticated by having been transformed, incorporated or embodied into an official representation. ${ }^{105}$ We need to be sure, these authors say, swearing together, about the appropriate dividing line between what Coke said and the present reality today. The 'reality' today, we are told, is that judicial review is and cannot legitimately be anything but a more or less (depending on who is talking) ${ }^{106}$ restricted form of supervision which concerns itself with the legality or validity of an administrative or executive decision (sometimes said to overlap with the merits). ${ }^{107}$ As should be clear, there is no space for justice in this model, except insofar as justice is viewed as incorporated into law. Judicial supervision in this model is simply the administering of a pre-determined programme where nothing radically new is allowed to happen. Coke's talk of correcting every error ('no wrong or injury, either publick or private, can be done, but that all this shall be reformed or punished') is regarded as dangerous, outrageous, revolutionary.

\footnotetext{
${ }^{99}$ This is the case irrespective of whether judicial review is regarded as being authorized by the common law, a specific statute, the ultra vires doctrine or a supreme Constitution.

${ }^{100}$ See also A.D. Boyer, "Understanding, Authority, and Will": Sir Edward Coke and the Elizabethan Origins of Judicial Review', Boston College Law Review 39/December (1997), 43-93 at 92; Stoner, supra n. 57, at 30.

${ }^{101}$ Derrida and Roudinesco, supra n. 54, at 80, 81.

102 J. Defoort, Wet en Geweld: Over Recht en Gerechtigheid (Kapellen: Uitgeverij Pelckmans, 1994), 156.

${ }^{103}$ See Derrida supra n. 1, at 108, 141.

${ }^{104}$ Derrida Ibid at 136 explains that the difference between spectre and spirit is a différance: 'The specter is not only the carnal apparition of the spirit, its phenomenal body, its fallen and guilty body, it is also the impatient and nostalgic waiting for redemption, namely, once again, for a spirit... The ghost would be a deferred spirit, the promise or calculation of an expiation. What is this differance? All or nothing. One must reckon with it but it upsets all calculations, interests, and capital.'

${ }^{105}$ See F. Jameson, 'Marx’s Purloined Letter' New Left Review 209 (1995) 75-109 at 95.

106 See eg Lord Steyn, 'Deference: a Tangled Story Public Law Summer (2005) 346-359 on the differences between Lord Hoffmann and himself on the issue of deference.

${ }^{107}$ See eg P. Leyland and T. Woods, Textbook on Administrative Law (Oxford: Oxford University Press, $4^{\text {th }}$ ed, 2002), 229-232; M.T. Molan, Administrative Law (London: Old Bailey Press, $4^{\text {th }}$ ed, 2003), 18-20; Wade and Forsyth, supra n. 13, at 33-35; J. Alder, Constitutional and Administrative Law (Hampshire: Palgrave Macmillan, $5^{\text {th }}$ ed, 2005), 361; Craig, Administrative Law supra n. 15, at 7-9. Wade and Forsyth (at 34) and Alder (at 358) acknowledge an overlap between merits and legality, as do Craig, Administrative Law 8-9, 516; Aronson et al, Judicial Review of Administrative Action (Pyrmont, NSW: Thomson/Lawbook Co, 3d ed, 2004), 156-166; and Hoexter, supra n. 15, at 64-65, 184-185.
} 
These authors are of course right in a certain sense. What Coke said with regard to jurisdiction and justice would be asking of judges to do the impossible; judicial supervision and justice in accordance with law can become possible only by placing restrictions on, by forgetting, deferring, repressing this desire for justice and for the exercise of an unlimited jurisdiction (the impossible).108 Coke's 'sweeping' jurisdiction (the desire for the impossible), we can say, can never present itself as such. To make this unconditional or unlimited jurisdiction effective, it has to be limited, it has to become determinate, conditional, restricted. ${ }^{109}$ Even though a limited jurisdiction can be said to effectively destroy the notion of an unlimited jurisdiction, a trace of the impossible, the trace of its withdrawal, nevertheless always remains within the possible; the possible continues to be haunted by the impossible. ${ }^{110}$ The desire for the impossible thus remains, because of the permanent out-of-joint-ness of that which is possible (law's lack of justice). ${ }^{111}$ Coke's ghosts will therefore surface again and again (in the unconditional promise ${ }^{112}$ contained in the concept of 'jurisdiction' to supervise the administration and in the call of those who are excluded from administrative justice) in spite of this oath of allegiance, this hegemony (which Coke himself, or rather someone in him, shares with today's authors) that organises the repression and which thereby paradoxically confirm the haunting. ${ }^{113}$ The 'reality' today which the authors on judicial review describe can thus rather be termed a very intricate unreality:114 a spectre thus, neither pure body nor pure spirit. ${ }^{115}$

Should we be prepared to face our anxieties, to risk our homes, our preservation, our needs, and not drive away the ghosts of Coke so eagerly, in such good conscience, ${ }^{116}$ but allow them to come back, to welcome them, dare we then, in light of our reflections on Coke and justice, assert the following: When Coke sets out the jurisdiction of the King's Bench as it relates to the supervision of inferior jurisdictions (in James Bagg's Case and in the Institutes), he is saying the following: Firstly, the concept of jurisdiction involves two contradictory but indissociable things: The one is a desire for justice. This does not refer simply to what you would today call exercising

\footnotetext{
${ }^{108}$ M. Naas, Taking on the Tradition: Jacques Derrida and the Legacies of Deconstruction (Stanford: Stanford University Press, 2003), 162.

${ }^{109}$ G Borradori, Philosophy in a Time of Terror: Dialogues with Jürgen Habermas and Jacques Derrida (Chicago: The University of Chicago Press, 2003), 129-130.

${ }^{110}$ Derrida Negotiations supra n. 2, at 359, 361, 362.

111 J. Derrida and M. Ferraris, A Taste for the Secret (Malden, MA, USA: Polity Press, 2001), 6.

112 The saying of St Jerome, repeated by Coke in the epigram should in other words be read with what Derrida, in Caputo, supra n. 5, at 22-23 says on faith and the promise: 'You cannot address the other, speak to the other, without an act of faith, without testimony. What are you doing when you attest to something? You address the other and ask, "believe me." Even if you are lying, even in perjury, you are addressing the other and asking the other to trust you.... Each time I open my mouth, I am promising something. When I speak to you, I am telling you that I promise to tell you something, to tell you the truth. Even if I lie, the condition of my lie is that I promise to tell you the truth. So the promise is not just one speech act among others; every speech act is fundamentally a promise' (footnote omitted).

${ }^{113}$ Derrida, n. 56, at 34-35.

${ }^{114}$ See Jameson, supra n. 105, at 102.

${ }^{115}$ See E. Laclau 'The time is out of Joint' 25/2 (1995) Diacritics 86-96 at 87.

${ }^{116}$ See Boyer, supra n. 100, at 60-61 on Coke, reliance on precedent and a good conscience.
} 
an appeal or a more restricted review function or granting the remedies you associate with it. It refers to the supervision of all errors and misdemeanours, all public and private wrongs, any manner of misgovernment ${ }^{117}$ - a jurisdiction without any limits as well as to the reformation of all errors and misdemeanours. The remedial function does not mean simply compensating a wrong or restituting something that is due, but to give beyond due - a gift without restitution, without calculation, without accountability. ${ }^{118} \mathrm{~A}$ judge must nevertheless also decide according to the law and take account of the particular socio-economic, political context, which inevitably implies placing restrictions on the specific parties who are allowed to come to court and the scope of supervision. It also means granting orders which can indeed practically, albeit imperfectly, remedy the situation at hand without placing an undue burden on the state administration. ${ }^{119}$ At different times and different places, these restrictions, which are always necessary, but never completely justified, will take on different forms. The relation between law and justice in other words involves undecidability, a double bind: we have a desire for justice and we have to judge in accordance with law. ${ }^{120}$ It is here, in the differential and deferential relationship, in enduring the antinomy between law and justice, that responsibility lies. Jurisdiction, in addition to attempting to stabilize the future, contains a promise of a justice to come; it says something of the future; it implies something for future decisions. One never knows what the future will hold; the future remains to be decided and it can only be decided by traversing the limit between law and justice. As Derrida says -

[i]f the stabilized stability of certainty is never given, if it is conquered in the course of a stabilization, then the stabilization of what becomes certain must cross - and therefore, in one way or another, recall or be reminded of - the suspended indecision, the undecidable qua the time of reflection..$^{121}$

Secondly, the law (here referring specifically to the law relating to judicial supervision and separation of powers) must, in every case, if we are to do justice, be suspended so as to create it anew. ${ }^{122}$ In some instances this may require transgressing the traditional limits of supervision and the creation of a new remedy ('out of whole cloth' as Jaffe ${ }^{123}$ says) as was done in James Bagg's Case. Remedies, it must be kept in mind, should still be distinguished from doing justice. In order for a decision in judicial supervision proceedings to be just, it cannot thus simply preserve that which has been established. In establishing the institution of judicial supervision justice is

\footnotetext{
117 See K.C. Wheare, Maladministration and its Remedies (London: Stevens \& Sons, 1973), 6-14; and G. Marshall, 'Maladministration', Public Law Spring (1973), 32-44 on the potentially wide meaning of maladministration (misgovernment).

${ }^{118}$ Derrida, supra n. 1, at 25. G. Abraham, 'Historical Jurisprudence', in C. Roederer and D. Moellendorf Jurisprudence (Cape Town: Juta \& Co Ltd, 2004), 117-137 at 135 reports that Coke said that 'history [is] a faith rather than science'. The act of faith, as Derrida, supra n. 48, at 16 points out, 'belongs - it must belong - to what is incalculable in decision'.

${ }^{119}$ See De Ville, supra n. 17, at 477-478.

${ }^{120}$ Derrida, supra n. 85, at 24-26.

${ }^{121}$ Derrida, supra n. 48, at 15.

${ }^{122}$ Derrida, supra n. 85, at 22-24.

${ }^{123}$ Supra n. 12, at 331.
} 
deferred and the differential relationship between law and justice is instituted.124 This is repeated in every act of judicial supervision: justice can only, but at the same time cannot be brought about through law. Law (whether understood as statutory law, common law or custom), with its origins clouded in the mists of time, is never to be equated with justice and is ultimately a violence without ground. ${ }^{125}$ This is not a sceptical or nihilistic argument. Judicial supervision which simply entails applying the existing law and which does not suspend and re-found the law would have no relation to justice. ${ }^{126}$ Every instance of judicial supervision is in effect a celebration, a suspension, a re-institution and a re-justification of this revolutionary moment.127 Judges are called upon to be revolutionaries. Thirdly, understanding the common law as perfect reason admittedly allows for evolution and growth in accordance with the values of the community. At the same time, it implies a period of waiting. Justice, on the other hand, requires urgency, justice does not wait. Justice requires a decision that disrupts the values of the 'community' at a specific point in time. ${ }^{128}$

\section{CONCLUSION}

Why should we read the origins of judicial review as suggested above? Perhaps the answer lies in Hannah Arendt's book on the trial of Adolf Eichmann, prosecuted for his role as chief architect and executioner of the 'final solution' to the 'Jewish problem'. ${ }^{129}$ Arendt coined the phrase 'the banality of evil' to describe the actions of Eichmann, someone whom she regarded as not being an evil man with a hatred for Jews, but an innocuous individual who simply followed orders in the same way in which other bureaucratically assigned responsibilities would have to be carried out. He was a 'joiner', a conformist, 'a leaf in the whirlwind of time', ${ }^{130}$ and a 'terribly and terrifyingly normal' man. ${ }^{131}$ The 'orders' in the context of judicial review, it could be argued, are the restrictions (currently regarded as 'acceptable both to the judges and to public opinion', or 'apt for our needs today', as Jaffe and Henderson ${ }^{132}$ might put it) on the duty to 'provide justice to all and singular of our realm': the restrictions imposed on justice 'for our preservation'; for 'the tranquillity of our realm'. These restrictions are those limiting access to the courts, limiting the scope of review (usually to the exercise of public rather than private powers), the standard of review (proportionality or correctness on the one hand and a very deferential rationality standard which can effectively turn the issue into a non-justiciable one on the other) and the remedies that may be granted. These restrictions may not necessarily cause

\footnotetext{
${ }^{124}$ Derrida, supra n. 85, at 23: '[I]n the founding of law or in its institution, the same problem of justice will have been posed and violently resolved, that is to say buried, dissimulated, repressed.'

${ }^{125}$ Ibid., at 14; Derrida, Negotiations supra n. 2, at 115.

${ }^{126}$ Defoort, supra n. 102 , at 158.

${ }^{127}$ Ibid.

${ }^{128}$ Derrida, supra n. 85, at 26.

${ }^{129}$ H. Arendt, Eichmann in Jerusalem: A Report on the Banality of Evil (New York: Viking Press, 1963).

${ }^{130}$ Ibid., at 32.

${ }^{131}$ Ibid., at 276.

${ }^{132}$ Supra n. 12, at 345.
} 
death, ${ }^{133}$ but they often have a severe impact on the inequalities that are tolerated within, on and beyond the borders of nation-states (for example in relation to housing, land, health, water, food, electricity, education, employment, social security and access to justice) and on those who find themselves in other ways excluded (by being imprisoned or detained, often in deplorable conditions, or forcefully excluded through border controls or for reasons of national security) because of unequal freedom. ${ }^{134}$ In some common law countries, and I am thinking here specifically of South Africa, the inefficiency and apathy of state organs and officials tasked to bring about greater equality as well as budget preferences which do not reflect this concern, constitute some of the major injustices. ${ }^{135}$ The death and destruction caused by the arms industry, which form a major part of Western economies and which usually manage to escape from judicial supervision, also require mention as do environmental injustices which are often the consequence of 'economic freedom'. ${ }^{136}$ The judges in the common law world may never (again) ${ }^{137}$ have to answer for how they have exercised their supervisory jurisdiction. This does not however absolve judges from their responsibility as heirs, also of Coke's writings. One of Coke's spirits 'keeps trying to reach us, to speak to us, to summon us to live otherwise - that is, more justly - and urges us not to forget that we are the heirs of a never fulfilled promise': 138 to bring about justice.

This is not to say that there should be no limits on access to the courts, the scope of review, the grounds of review, or the remedies that may be granted; neither does it mean that there should not be different standards of review. The survival of constitutional democracy (our preservation) ultimately depends on such limits. Remaining faithful to this spirit of Coke will nevertheless imply a loosening of 'our grip on [these] traditional points of reference in deference to the singularity of the here-right-now'. ${ }^{139}$ These elements of judicial review thus need to constantly remain open to transformation, re-evaluation and reinterpretation. ${ }^{140}$ Coke ends the Epilogue to the Fourth part of the Institutes, after he had elaborated on the jurisdiction of the courts, by calling upon his heirs to -

amend both the method or uniformity, and the structure it selfe, wherein they shall find either want of windowes, or sufficient lights, or other deficiency in

\footnotetext{
${ }^{133}$ Derrida, supra n. 8, at 86 reminds us that there is little difference between killing someone and letting someone die.

${ }^{134}$ See Derrida, supra n. 47 , at 49 on equality and freedom.

135 For a recent discussion of remedies that could alleviate some of these problems, see K. Roach and G. Budlender, 'Mandatory Relief and Supervisory Jurisdiction: When is it Appropriate, Just and Equitable?', South African Law Journal 122 (2005), 324-351.

${ }^{136}$ See J.D. Caputo, The Prayers and Tears of Jacques Derrida: Religion without Religion (Bloomington \& Indianapolis: Indiana University Press, 1997), 125-126; Derrida, supra n. 1, at 81-84.

${ }^{137}$ See D. Dyzenhaus, Truth, Reconciliation and the Apartheid Legal Order (Cape Town: Juta \& Co Ltd, 1998) on the South African Truth and Reconciliation Commission.

${ }^{138}$ See K. de Boer, 'Enter the Ghost/Exit the Ghost/Re-Enter the Ghost: Derrida's Reading of Hamlet in Specters of Marx', Journal of British Society for Phenomenology 33/1 (2002), 22-38 at 25 on Marx's spectre.

${ }^{139}$ T. Lorraine, 'Living a Time out of Joint' in P. Patton and J. Protevi, eds., Between Deleuze and Derrida (London and New York: Continuum, 2003), 30-45 at 31.

${ }^{140}$ Derrida, supra n. 1 at 88.
} 
the Architecture whatsoever. And we will conclude with the Aphorisme of that great Lawyer and Sage of the Law (which we heard him often say) Blessed be the amending hand. ${ }^{141}$

One of Coke's spirits continues to call upon us, seeks to persuade us, orders us (perhaps, if we could see it, through a writ of mandamus) to question the limits in every new context, 'on account of the necessity of doing justice..142 In every new context where it becomes an issue, the institution of judicial supervision, of administrative justice, must be both asserted and undermined. Coke's mandamus - a remedy which speaks of command, obligation and force, but which also invokes the spirit of the pure gift and of absolute hospitality and which may possibly be the ultimate giving remedy to come - could play an important role in this regard.

University of the Western Cape

Faculty of Law

Private Bag X17

Bellville

7535

South Africa

E-mail:jdeville@uwc.ac.za

${ }^{141}$ Sir Edward Coke, The Fourth Part of the Institutes of the Laws of England (New York: Garland Publishing Inc, 1979). See also Derrida, supra n. 1, at 13 on Marx who called for the transformation to come of his own theses.

${ }^{142}$ See the Fourth Part of the Institutes quoted above. 